\title{
Lung cancer among young patients in Dharmais Cancer Center Hospital, Jakarta (1994-1998)
}

\author{
Anwar Jusuf*, Noorwati Sutandyo**, Sariasih Arumdati**, Erlina Burhan*, Eddy Suratman**, \\ A. Mulawarman Jayusman**
}

Abstrak

Kanker paru biasanya ditemukan pada usia tua dan usia pertengahan. Dari tahun 1994 sampai dengan tahun 1998, telah dirawat di RS Kanker Dhannais, 37 penderita yang berumur 40 tahun ke bawah, merupakan 5,9\% dari seluruh penderita kanker paru yang dirawat selama masa tersebut. Penyakit ini ditemukan lebih banyak pada laki-laki (perbandingan kekerapan laki-laki dan perempuan adalah 3:1), kelompok umur 2640 tahun. Sebagian terbesar pasien termasuk stage IV (48,7\%). keluhan utama adalah sesak napas $(58,1 \%)$ dan nyeri (32,5\%). Kanker paru jenis karsinoma bukan sel kecil terbanyak ditemukan (91,9\%), karsinoma sel kecil sebanyak 2,7\% dan pada 5,4\% jenis histologis tidak dapat ditentukan. Pengobatan yang dipilih ialah pembedahan pada 9 kasus, radioterapi pada 17 kasus dan kemoterapi 5 kasus. Empat belas pasien (38\%) meninggal di rumah sakit, sisanya tidak dapat diikuti. (Med $\mathbf{J}$ Imrones 2001; IO: 73-8)

Abstract

Lung cancer is usually seen in patients of middle and old age. The disease is rarely seen in patients under 40 years. Jn Dhannais Cancer Center Hospital 37 patients of 40 years of age or younger were seen. The number was 5.9\% of the total of lung cancer cases that was seen in this hospital in 1994 - 1998. The disease was more dominant among males (male to female ratio 3 : 1), age between 26 - 40 years. Most of the patients were stage JV (48.7\%), chief complaints were dyspnea (58.1\%) and pain (32.5\%). Nonsmall cell carcinoma was the most frequent histologic type (91.9\%), small sell carcinoma was seen in $2.7 \%$ and in $5.4 \%$ the histologic type could not be detennined. The treatment consisted of surgery in 9 cases, radiotherapy in 17 cases and chemotherapy in 5 cases. Fourteen patients (38\%) died in hospital, the rest were notfollowed further .(Med J Indones 2001; 10: 73-8)

Keywords : Lung cancer, young age

As in other countries in the world, lung cancer is increasing in Indonesia. This malignant disease is quite common among males of the middle age and especially smokers, but is not very frequent among those under 40 years of age. Previous studies have reported that only 1 to 6 percents of patients with lung cancer are younger than forty years of age. ${ }^{1-5}$ Some have suggested that the clinical behavior of lung cancer in young patients is more aggressive compared with bronchogenic cancer diagnosed in elder patients. ${ }^{\text {I }}{ }^{2}$

\section{MATERIAL AND METHODS}

We reviewed all the cases of lung cancer in patients of 40 years of age or younger who were hospitalized in Dharmais Cancer Center Hospital from January

*) Department of Respiratory Medicine, Faculty of Medicine, University of Indonesia/Persahabatan Hospital, Jakarta, Indonesia

**) Dharmais Cancer Center Hospital, Jakarta, Indonesia
1994 until December 1998. The Dharmais Cancer Center Hospital in Jakarta is one of the teaching hospitals for the Faculty of Medicine, University of Indonesia. There were 622 lung cancer patients seen during the period of 1994-1998. They were managed according to the lung cancer protocol of the Faculty of Medicine, University of Indonesia. The materials for this report were taken from the medical records of the hospital during the period. The inclusion criterias are:

Clinical and radiological diagnosis of lung cancer, with or without histological diagnosis

Age : 40 years or younger

The items for analysis are :

- sex, age

- chief complaints

- radiological abnormalities

- histologic type according to WHO Classification 1981

- stage of disease according to UICC I AJCC 1997

- sites of metastasis

- treatment modalities

- outcome after treatment

- smoking habit 


\section{RESULTS}

During 1994-1998, 37 lung cancer patients of 40 years or younger were seen. This number is $5.9 \%$ of 622 lung cancer patients administered in the Dharmais Hospital during the same period. There were 28 males $(75,7 \%)$ and 9 females $(24,3 \%)$ that makes male : female ratio approximately 3: 1 . Table 1 shows the distribution of the patients according to their age.

Table I. The Distribution of Lung Cancer Patients Among Young Patients According to Age at Dharmais Cancer Center Hospital 1994-1998

\begin{tabular}{ccc}
\hline Age (years) & $\mathrm{N}$ & $\%$ \\
\hline $11-15$ & & \\
$16-20$ & & 2.7 \\
$21-25$ & 6 & 16.2 \\
$26-30$ & 11 & 29.8 \\
$31-35$ & 18 & 48.6 \\
$36-40$ & 1 & 2.6 \\
Not recorded & 37 & 100 \\
\hline Total & &
\end{tabular}

Table 2 shows the chief complaints of the patients. Dyspnea alone or in combination with other complaints was seen in 20 (54\%) of patients, followed by pain alone or with other symptoms in 12 (32\%), and cough alone or with dyspnea in 7 patients $(18,9 \%)$

Table 2. Chief Complaints of Lung Cancer Among Young Patients in Dharmais Cancer Center Hospital, 19941998

\begin{tabular}{lcc}
\hline \multicolumn{1}{c}{ Chief Complaints } & $\mathrm{N}$ & $\%$ \\
\hline Cough & 5 & 13.5 \\
Cough and dyspnea & 11 & 29.8 \\
Dyspnea & 2 & 5.4 \\
Chest pain and dyspnea & 2 & 5.4 \\
Oyspnea, pain and nodule in chest wall & 2 & 5.4 \\
Severe dyspnea and nodule in the neck & 1 & 2.7 \\
Chest pain & & 2.7 \\
Discomfort in the back \& chest pain & 2 & 5.4 \\
Nodule in the neck & & 2.7 \\
Bone pain & 4 & 10.8 \\
Headache & 2 & 5.4 \\
Stomach discomfort & & 2.7 \\
Nausea & 1 & 2.7 \\
Unspecified & 2 & 5.4 \\
& 37 & 100 \\
\hline
\end{tabular}

Table 3 shows the chest X-ray abnormalities among the patients. The majority of them had a nodular mass of more than 3 centimeters, with or without other abnormalities like atelectasis, pleural effusion, pneumothorax.

Table 3. Chest X-Ray Abnormalities of Lung Cancer in Young Patients, Dharmais Cancer Center Hospital, 19941998

\begin{tabular}{|c|c|c|}
\hline Chest X-Ray Abnormality & $\mathrm{N}$ & $\%$ \\
\hline$>3 \mathrm{~cm}$ Nodule & 9 & 24.3 \\
\hline$>3 \mathrm{~cm}$ Nodule + Atelectasis & 2 & 5.4 \\
\hline$>3 \mathrm{~cm}$ Nodule + Pleural Effusion & 1 & 2.7 \\
\hline$>3 \mathrm{~cm}$ Nodule + Atelectasis + Pleural Effusion & 2 & 5.4 \\
\hline > 3 cm Nodule + Pneumothorax + others & 1 & 2.7 \\
\hline$>3 \mathrm{~cm}$ Nodule + others & 2 & 5.4 \\
\hline$<3 \mathrm{~cm}$ Nodule + Pleural Efussion & 3 & 8.1 \\
\hline Atelectasis + Pleural Effusion & 2 & 5.4 \\
\hline Pleural Effusion & 5 & 13.5 \\
\hline Others & 8 & 21.6 \\
\hline Not recorded & 2 & 5.4 \\
\hline Total & 37 & 100 \\
\hline
\end{tabular}

The histological diagnosis of the patients are shown in Table 4. There was only one case of small cell carcinoma (2,7\%), 34 patients $(91,9 \%)$ belonged to nonsmall cell carcinoma and in 2 cases $(5,4 \%)$ the histological diagnosis could not be determined.

Table 4. The Histological Diagnosis of Lung Cancer in Young Patients, Dharmais Cancer Center Hospital, 19941998

\begin{tabular}{llc}
\hline \multicolumn{1}{c}{ Histological Diagnosis } & N & $\%$ \\
\hline Squamous Carcinoma & 10 & 27 \\
Adenocarcinoma & 18 & 48.7 \\
Large Cell Carcinoma & 2 & 5.4 \\
Adenosquamous Carcinoma & 3 & 8.1 \\
Nonsmall Cell Carcinoma & & 2.7 \\
Small Cell Carcinoma & & 2.7 \\
Not Recorded & 2 & 5.4 \\
\hline \multicolumn{1}{c}{ Total } & 37 & 100 \\
\hline \multicolumn{1}{c}{}
\end{tabular}

Table 5 shows the stage of the disease among the patients. Most of the patients $(48,7 \%)$ were seen in stage IV; $5,4 \%$ were in stage IIIA. In 40,5\% of case:; the stage of disease can not be determined. There were no stage IA, IIA, IIB and IIIB disease. 
Table 5. Staging of Lung Cancer in Young Patients, Dharmais Cancer Center Hospital, 1994-1998

\begin{tabular}{lcc}
\hline Stage of Disease & $\mathrm{N}$ & $\%$ \\
\hline Stage IA & 2 & 5.4 \\
Stage IB & & \\
Stage IIA & & \\
Stage IIB & 2 & 5.4 \\
Stage IIIA & & \\
Stage IIIB & 18 & 48.7 \\
Stage IV & 15 & 40.5 \\
Not determined & 37 & 100 \\
\hline Total & & \\
\hline
\end{tabular}

Table 6, 7 and 8 show the site of metastasis as shown by CT Scan of the brain, bone scanning and USG of the abdomen. Brain CT Scanning was not performed in 20 patients, in 9 patients there was no record concerning this test. Among 8 patients who underwent CT of the brain, 4 patients show positive result of brain metastasis and in 4 patients, metastasis was not found.

Bone scanning showed metastasis in 12 patients, in 4 patients the result was negative and 8 patients the record was not found. The test was not performed in 13 patients. Ultrasonography of the abdomen showed liver metastasis in 5 patients, in 3 patients metastasis were found in other organs. No metastasis were seen in the abdomen in 9 cases and the record was not found in 8 patients. The procedure was not performed in 12 patients.

Table 6. Brain Metastasis Shown by Brain CT Scanning in Lung Cancer Among Young Patients, Dharmais Cancer Center Hospital, 1994-1998

\begin{tabular}{lcc}
\hline Brain Metastasis in Brain CT & N & $\%$ \\
Brain Metastasis Positive & 4 & 10.8 \\
Brain Metastasis Negative & 4 & 10.8 \\
Not Performed & 20 & 54.1 \\
Not Recorded & 9 & 24.3 \\
\hline \multicolumn{1}{c}{ Total } & 37 & 100 \\
\hline
\end{tabular}

Table 7. Bone Metastasis Shown in Bone Scanning in Lung Cancer Among Young Patients, Dharmais Cancer Center Hospital, 1994-1998

\begin{tabular}{|c|c|c|}
\hline Metastasis in Bone Scanning & $\mathrm{N}$ & $\%$ \\
\hline Bone Metastasis Positive & 12 & 32.4 \\
\hline Bone Metastasis Negative & 4 & 10.8 \\
\hline Not Performed & 13 & 35.2 \\
\hline Not Recorded & 8 & 21.6 \\
\hline Total & 37 & 100 \\
\hline
\end{tabular}

Table 8. Abdominal Metastasis Shown by Ultrasonography in Lung Cancer Among Young Patients, Dharmais Cancer Center Hospital, 1994-1998

\begin{tabular}{|c|c|c|}
\hline Seri Kemoterapi & $\mathrm{N}$ & $\%$ \\
\hline Liver Metastasis Positive & 5 & 13.5 \\
\hline Metastasis to Other Abdominal Organs & 3 & 8.1 \\
\hline No Abdominal Metastasis & 9 & 24.3 \\
\hline Not Performed & 12 & 32.4 \\
\hline Not Recorded & 8 & 21.7 \\
\hline Total & 37 & 100 \\
\hline
\end{tabular}

Table 9 records the surgical treatment of the patients. Nine patients were treated with surgery. Six patients had lobectomy, 1 had superior vena cava by-pass surgery, 2 patients had other type of surgery. No record was available in 4 patients and in 24 patients surgery was not performed.

Table 9. Surgery in Lung Cancer Among Young Patients, Dharmais Cancer Center Hospital, 1994-1998

\begin{tabular}{|c|c|c|}
\hline Type of Surgery & $\mathrm{N}$ & $\%$ \\
\hline Lobectomy & 6 & 16.2 \\
\hline By-pass Surgery on Superior Vena Cava & & 2.7 \\
\hline Others & 2 & 5.4 \\
\hline Not Performed & 24 & 67.6 \\
\hline Not Recorded & 4 & 10.8 \\
\hline Total & 41 & 100 \\
\hline
\end{tabular}


Eighteen patients were treated with radiotherapy. In 3 patients the records were not available and in 17 patients radiotherapy was not performed. The majority of the irradiated patients had a total radiation dose between 4000-6000 mcg (Table 10).

Table 10. Total Dose of Radiotherapy for Lung Cancer Among Young Patients Dharmais Cancer Center Hospital, 1994-1998

\begin{tabular}{ccc}
\hline Radiation Dose (cGy) & N & $\%$ \\
\hline$<2000$ & 3 & 8.1 \\
$2000-3000$ & 2 & 5.4 \\
$3000-4000$ & 5 & 13.5 \\
$4000-5000$ & 2 & 5.4 \\
$5000-6000$ & 4 & 10.8 \\
$>6000$ & 2 & 5.4 \\
Not Performed & 17 & 45.9 \\
Not Recorded & 2 & 5.4 \\
Total & 37 & 100 \\
\hline
\end{tabular}

Chemotherapy was administered to 5 patients, no record was available in 27 patients, while in 5 patients chemotherapy was not indicated. Table 11 shows the drug combinations that were used in the series

Table 11. Chemotherapy for Lung Cancer In Young Patients, Dharmais Cancer Center Hospital, 1994-1998

\begin{tabular}{ccc}
\hline Drug Combination & $\mathrm{N}$ & $\%$ \\
\hline CAP II *) & & 2.7 \\
Taxol-Carboplatin & 2.7 \\
CAMP **) & 2.7 \\
Others & 2 & 5.4 \\
Not Administered & 5 & 13.5 \\
Not Recorded & 27 & 73 \\
\hline Total & 37 & 100 \\
*) CAP II : Cyclophasphmide, doxorubicine, cisplatin \\
**) CAMP: Cyclophasphamide, doxorubicine, methotrexate, \\
procarbazine
\end{tabular}

After treatment, 14 patients died in hospital, the remaining 23 patients were lost to follow up.

The smoking habit of the patients were recorded in only 20 patients. Five patients were nonsmokers, 15 were smokers and there were no record concerning this habit in 17 cases. The daily cigarette consumption among the smokers were 1-10 cigarettes in 4 patients,
11-20 in 4 patients, $21-40$ cigarettes in 2 patients and more than 60 cigarettes in 1 patient. None of them smoked 41-60 cigarettes per day and in 4 patients the daily consumption was not recorded (Table 12).

Table 12. Daily Consumption of Cigarettes in Young Patients with Lung Cancer Dharmais Cancer Center Hospital, 1994-1998

\begin{tabular}{ccc}
\hline $\begin{array}{c}\text { Number of Cigarettes } \\
\text { Consumed per day }\end{array}$ & $\%$ \\
\hline Nonsmoker & 5 & 13.5 \\
$1-10$ & 4 & 10.8 \\
$11-20$ & 4 & 10.8 \\
$21-40$ & 2 & 5.4 \\
$>40$ & & 2.7 \\
Number not recorded & 4 & 10.8 \\
No record on smoking & 17 & 45.9 \\
\hline Total & 37 & 100 \\
\hline
\end{tabular}

\section{DISCUSSION}

Our finding reveals 5.9\% lung cancer among patient!; of 40 years of age or younger. This figure was similar to those reported previously by several centers. ${ }^{15}$ Other investiga tors of course, had higher figures such as $8 \%$ found by Bourke et.al. ${ }^{6}$ Earlier study in Persahabatan Hospital ${ }^{7}$ showed that $15.2 \%$ of the lung cancer cases were in young age group. Our data corroborate previous indication that adenocarcinoma are common among the young patients. Report from Persahabatan Hospital Jakarta gave the figure of $38.1 \%$ of adenocarcinoma among the young patients. In general, though squamous cell carcinoma has for many years been the most common histologic type, adenocarcinoma has been increasing in incidence in recent years, a trend which has been demonstrated in severa1reports. ${ }^{2-4} \cdot 6-10$

Regardless of age, lung cancer is still discovered as symptomatic disease as emphasized by the fact that $94.6 \%$ of patients in our series were symptomatic. We documented a high incidence of dyspnea (29.8\%) as the chief complaint, and combination with other complaints were seen in $58.1 \%$ of patients. Chest pain alone or combined with other complaint and cough with or without other complaints also. showed high incidence. These complaints are, as reported by others, are the symptoms of the late stage of disease. 
Kyriakous and Webber ${ }^{10}$ reported weight loss as a chief complain, however in our study this complain was not recorded.

Seventeen out of 37 (67.6\%) patients showed $>3 \mathrm{~cm}$ nodule in the chest X-ray film, with or without other abnormalities such as atelectasis, pleural effusion, pneumothorax and others. Similar condition was reported by De Caro et al showing that 21 cases out of 35 (60\%) are considered as T2 and T3 cases. ${ }^{1}$

Metastasis were seen in the brain (10.8\%), bone (32.4\%) and liver and abdominal organs (21.6\%), although in $21-24 \%$ of patients no record was available. In accordance with the symptoms, most of our patients were in the stage IV (48\%). The similar finding was reported by Green, who found out that 44 of out 48 (91.7\%) were first seen in stage IV. ${ }^{4}$ The same finding was suggested by Bourke ${ }^{6}$ and Giriputro ${ }^{7}$ which were $40-46 \%$, and $66.6 \%$ respectively. These datas show that both public and professional awareness is limited since bronchogenic carcinoma in this age group is uncommon. Young patients may not suspect serious illness. Moreover, physicians often may not suspect an underlying carcinoma despite persistent pulmonary symptoms, especially in our setting where pulmonary tuberculosis is still the predominant cause of many respiratory symptoms.

Eighteen patients had radiotherapy, 9 had surgery and 5 had chemotherapy as treatment. Radiotherapy was the most frequent modality chosen for the patients, while chemotherapy was administered only in $14.5 \%$ of patients. This fact was controversial to the fact that most of the cases were stage IV, for which chemotherapy was more indicated while the performance status allowed. The reason for this maybe due to financial problem. As most of Indonesians, most of the patients were not covered by insurance. They have to pay all the costs of diagnostic as well as the therapeutic procedures. Since in our country radiotherapy costs less expensive than chemotherapy, doctors often have to choose this modality as palliative treatment, even in stage IV cases, for example for bone pain, superjor vena cava syndrome etc. Number of surgery performed in our study was relatively low (6 lobectomy, l bypass surgery for superior vena cava and 2 other equations). Most of patients were since in late state. This may explain why in 24 patients in this study, surgery was not performed. Since there were only 4 stage IB and IHA patients, surgery were performed in relatively late stage patients as palliative treatment.
Cigarette smokinfi is accepted as the important cause of lung cancer ${ }^{1}{ }^{13}$ In young patients (95.2\%), however, many studies show different case. Giriputro et al showed that most young patients with lung cancer or $95.2 \%$ were non smokers. ${ }^{7}$ Green et al found $42 \%$ of never smokers in their study. ${ }^{4}$ In our series $13.5 \%$ of our cases were nonsmokers and $40.5 \%$ were smokers, the majority being heavy smoker. In spite of the lack of data concerning this habit in $45.9 \%$ of the cases, the number of smokers are large enough to consider smoking as a risk factor. The high figure of smoking history was also reported in their study by Pemberton et al, Jubelier and Wilson, Bourke et al, and Kyriakos and Webber which were $87 \%, 77 \%$, 81-90\%, and 94.1\% respectively. ${ }^{2} \cdot{ }^{36} .{ }^{10}$

We found in our study $48.7 \%$ cases, the stage can not be determined. This high figure might due to the fact that many of our patients or the family decided to go home much early even before the diagnostic procedures were performed. Financial problem and feeling of hopeless are most likely to be the cause. This early discharge by the patients or family wishes is perhaps responsible as well for incomplete data in metastasis and chemotherapy record.

This study and others demonstrated that lung cancer is no longer a disease of old male patients with smoking histories but also a diseases of young people, regardless of age and sex. Diagnostic test should be performed early to exclude the possibility of lung cancer among young patients who have persistent symptom of pulmonary diseases. It is also important to look for other factors in our population such as air pollu tion, nutrition, education, social economic status and genetic abnormalities, which could be related to the early development and severity of lung cancer. Further research, of course, need to be done.

This study is not supported by a very good record. The reason for this could be carelessness in recording base data like the age of patients (2.6\%), uncertain record of complaints and/or radiological abnormality (5.4\%) and histological diagnosis (5.4\%), total dose of radiotherapy (5.4\%), type of surgery $(10.8 \%)$ and the patients smoking habit (45\%). Other reasons may be lack of patient's compliance to diagnostic and staging procedure, treatment and follow up (Table 13). This is a very common condition in our country, since the patients have to pay all this procedure, while not all of them are covered by the insurance. 
Table 13. Missing datas and the possible cause

\begin{tabular}{lll}
\hline Possible cause & Missing datas & $\%$ \\
\hline Carelessness in & Age of patients & 2.6 \\
recording & Uncertain complaints & 5.4 \\
& Radiological abnormality & 5.4 \\
& Histological diagnosis & 5.4 \\
& Total dose of irradiation & 5.4 \\
& The type of surgery & 10.8 \\
& Smoking habit & 45.9 \\
& & \\
Patients' compliance to & Clinical stage & 20 \\
diagnostic procedure, & Cytostatic combination & 73 \\
treatment and follow up & Outcome of treatment & 62.6 \\
\hline
\end{tabular}

\section{CONCLUSIONS}

- Lung cancer in young patients (40 years or younger) were seen in $5.9 \%$ of the total number of case of lung cancer in Dharmais Cancer Center Hospital during the period 1994-1998

- Most of lung cancer among you ng patients were seen as advanced disease (stage IV)

- Adenocarcinoma was the most frequent histologic type in our study

- Hospital recording and reporting system need to be developed to ensure the complete and proper datas are available for research

- Both community and professional should be more aware of lung cancer among young people, so the disease could be found in the early stage

\section{Acknowledgement}

The authors wish to thank Mrs. Sunarti, S.Sos and Ms. Anggriani, SKM for typing and preparing this manuscript

\section{REFERENCES}

1. De Caro L, Berfield JR. Lung Cancer in Young Persons. J Thorac Cardiovase Surg 1982 ; 83 : 372-6

2. Pemberton JH, Nagomey DM, Gilmore JC, Taylor WF, Bematz PE. Bronchogenic carcinoma in Patients Younger than 40 years. Annual of Thoracic Surgery 1983 ; 36 : 509-15

3. Jubelirer SJ, Wilson RA. Lung Cancer in Patients Younger than 40 years of Age. Cancer 1991 ; 67 : 1436-8

4. Green LS, Fortoul TI, Panciano G, Robles C, Rivero 0. Bronchogenic Cancer in Patients under 40 years old. Chest 1993 ; $104: 1471-81$

5. Rocha MP, Fraire AE, Guntupalli KK, Greenberg SD. Lung Cancer in the young. Cancer-Detect-Prev 1994; 18 : 349-55

6. Bourke W, Milstein D, Giura R, Donghi M, Luisetti M, Rubbin AHE, Smith LJ. Lung Cancer in Young Adults. Chest $1992 ; 102: 1723-9$

7. Giriputro S, Rasmin M, Jusuf A. Kanker paru pada golongan usia muda di RS Persahabatan Jakarta. Jumal Respirologi Indonesia 1988; 8 : 13-8.

8. El Torkey M, El Zeky F, Hall JC. Significant Changes in the Distribution of Histologic Types of Lung Cancer. Cancer $1990 ; 65: 2361-7$

9. Valaitis J, Warren S, Gamble D. Increasing Incidence of Adenocarcinoma of the Lung Cancer. Cancer 1981 ; 47 : 1042-6

10. Kyriakos M. Webber B, Path FF. J Thorac Cardiovasc Surg $1974 ; 67: 634-47$

11. Jusuf A, Suryanto E, Hudoyo A. The relationship between Smoking and Lung Cancer in Persahabatan Hospital, Jakarta in : Cancer in Asia and Pacific. Indonesian Cancer Foundation, Jakarta 1998 :655-62

12. Samet JM, Wiggins CL, Humble CG, Rathak DR. Cigarette smoking and Lung Cancer in Mexico. AM Rev Respir Dis 1998; 137 : 1110-3

13. Ernster VL. Trendy Smoking Cancer Risk and Cigarettes Promotion. Cancer $1988 ; 62: 1702-12$

14. Breslow L, Cumberland WG. Progress and Objectives in Cancer Control. JAMA 1988 ; 259 : 1690-4

15. N, Triaspolitica. "Yang Perlu Anda Ketahui Tentang Penyakit Kanker Paru Paru, Gejala Umum, Penyebab, Serta Pengobatan." Mau Nanya Dong Dok. N.p, 29 June 2017. Web. 29 June 2017. <https://nanyadongdok.blogspot.com/2017/06/ yang-perlu-anda-ketahui-tentang.html $>$. 